Dr JASMINA MILANOVIĆ, viši naučni saradnik

Institut za savremenu istoriju

Beograd, Republika Srbija

jasmina.mil17@gmail.com

Prof. dr SANJA MILENKOVIĆ, redovni profesor

Kliničko bolnički centar Zemun

Beograd, Republika Srbija

sanjamilenkovic3@gmail.com

Prof. dr sc. MARINA KOS, redovni profesor

Medicinski fakultet Sveučilišta u Zagrebu

Zagreb, Republika Hrvatska

marina.kos@kbcsm.hr

prethodno saopštenje

UDK: 272-788.461-055.2(497.5)"18/19"

272-788.461-055.2(497.11)"18/19"

primljeno: 3. oktobar 2019.

$614.21(497.11+497.5) " 18 / 19 "$

prihvaćeno: 20. novembar 2019.

https://doi.org/10.29362/ist20veka.2020.1.mil.51-64

\title{
RAD MILOSRDNIH SESTARA SV. VINKA PAULSKOG U BOLNICAMA U ZEMUNU I ZAGREBU
}

APSTRAKT: Rad najstarije bolničke ustanove na teritoriji današnje Srbije - Zemunske bolnice neraskidivo je povezan sa dolaskom i radom milosrdnih sestara reda Sv. Vinka Paulskog. Red je počeo da se stvara 1617. godine kada je francuski sveštenik Vinsent de Pol (Vincent de Paul) počeo da okuplja žene koje su bile voljne da pomažu siromašnima i bolesnima, ali je zvanično osnovan 1633. godine. Prvih šest sestara je stiglo u Zagreb 1845. godine gde su u okviru samostana počele da neguju bolesnike. To će postati najstarija bolnica u Hrvatskoj. U Zemun su stigle 1887. kada su potpisale ugovor sa gradskim vlastima i preuzele upravu Gradske bolnice. Zahvaljujući njihovoj dobroj upravi i organizaciji bolnica je dobila novu zgradu i postala je moderna medicinska ustanova koja je pružala stručnu pomoć. Ovim bolnicama su upravljale i u njima radile sve do nacionalizacije 1948. godine.

KLJUČNE REČI: bolnica, milosrdne sestre, istorija medicine, Zagreb, Zemun

\section{Osnivanje reda Sv. Vincenta de Paula}

Francuski sveštenik Vinsent de Pol (1581-1660) počeo je 1617. godine da okuplja i organizuje prve grupe devojaka koje su dobrovoljno prihvatale da pružaju pomoć. Uglavnom su to bile žene skromnijeg porekla koje su želele da 
pomažu siromašnima i bolesnima u svojim selima ili parohiji. Od 1630. godine Vinsent je ove mlade devojke poverio na staranje i nadzor udovici Luiz de Marijak, koja mu je i ranije pružala podršku i pomoć. Kako su mlade žene bile raspoređene širom Pariza, Luiz je shvatila da je potrebno da ih okupi na jednom mestu kako bi rad mogao da se bolje organizuje i nadzire. Zato je, uz odobrenje Vinsenta, prvih šest žena dovela u svoj dom 29. novembra 1633. što se uzima i obeležava kao zvaničan datum osnivanja reda. Družba milosrdnih sestara - Filles de la Charite, koje su često zvali i Sestre milosrđa ili Kćeri milosrđa, bio je karitativni red koji je pomagao bolesne, siromašne, kao i sve koji su bili u nevolji. Dodatak „Sv. Vincent de Paul“ je dodat kasnije da bi se razlikovale od drugih zajednica milosrdnih sestara. Kada je 1660. godine Vinsent preminuo, milosrdne sestre su siromašne i bolesne zbrinjavale u svojim kućama u 26 parohija u Parizu, a u celoj Francuskoj je bilo već otvoreno još četrdeset kuća ovog reda. Vinsenta de Pola je proglasio blaženim papa Benedikt XIII 1729. godine, a svetim papa Klement XII 1737. godine. Brojne kuće u kojima su milosrdne sestre negovale bolesne bile su i mesta na kojima su obučavane nove sestre, koje su zatim svoj rad nastavljale i u drugim zemljama. Od 1750. milosrdne sestre su primljene u Švajcarskoj, a od 1778. godine stižu u Italiju. Šest sestara iz Pariza su 1790. godine otišle u Španiju i tu započele stvaranje zajednice. Do 1789. godine u Francuskoj je osnovano 426 kuća, a ukupan broj sestara u Evropi se procenjivao na 6.000. U vreme Francuske revolucije 1792. godine sestrama je naređeno da napuste matične kuće, da bi već naredne godine red milosrdnih sestara bio u Francuskoj zvanično ukinut i raspušten. Sa promenama političkih prilika došlo je 1801. godine do obnove reda, koji je imao veliki ugled $\mathrm{u}$ narodu. Posle toga dolazi do novog porasta broja pripadnica reda, a posebno u Francuskoj. Ubrzo su se pojavile i u Austriji, Portugalu, Mađarskoj, Engleskoj, Škotskoj, Irskoj, Severnoj i Južnoj Americi. Danas se ukupan broj članica ovog reda procenjuje na oko $25.000{ }^{1}$

U Sjedinjenim Američkim Državama prvu zajednicu je osnovala Majka Elizabet En Seton koja je 1810. usvojila pravila reda. U narednih dvadeset godina osnovana su sirotišta i škole u Sinsinatiju, Nju Orleansu i bolnica u Sent Luisu. Zajednice sestara su osnovane u Njujorku, Sinsinatiju, Halifaksu, Nju Džersiju, Grinsburgu. Elizabet En Seton je kanonizovana 1975. godine od strane pape Pavla VI. ${ }^{2}$

\section{Dolazak milosrdnih sestara u Zagreb i osnivanje prve bolnice}

Prvi zagrebački nadbiskup i kardinal Juraj Haulik pozvao je 1844. godine red milosrdnih sestara Sv. Vinka Paulskog da dođu u Zagreb. Još 1840. godine kupio je zemljište (danas u Frankopanskoj ulici) na kome je po njegovoj

\footnotetext{
${ }^{1}$ The Catholic Encyclopedia. New Advent 2012. http://www.newadvent.org/cathen/03605a.htm (pristupljeno 1. septembra 2018); Daughters of charity, http://www.daughters-of-charity.org/ history.htm (pristupljeno 1. septembra 2018).

2 The Sisters of Mercy, Our History, http://www.chsbuffalo.org/AboutUs/OurHistory (pristupljeno 1 . novembra 2018).
} 
naredbi izgrađen samostan za milosrdne sestre. Izgradnja samostana je započeta 1841. godine i trajala je do 1845. Iako je prvobitno bilo predviđeno da u Zagreb dođu milosrdne sestre iz Beča, one su odustale zbog izbijanja kolere jer je svaka milosrdna sestra u tim okolnostima bila potrebna. Zbog toga je nadbiskup Haulik uputio molbu episkopu Berhardu Galuru i on je poslao sestre iz Tirola.

Šsest sestara je stiglo u Zagreb septembra 1845, a rad sa pacijentima su otpočele 1. januara 1846. U bolnici koja je otvorena u južnom krilu samostana i imala u početku 12 kreveta, negovale su uglavnom ženske pacijente. Broj pacijenata je brzo rastao, pa su već 1849. godine negovale čak 243 bolesnice. Bolnica je u okviru samostana radila do 1871. godine i njom je upravljala superior reda. Od te godine bolnica je premeštena u ulicu Ilica br. 83, a dve godine potom postala je „Opšta bolnica“ kojom je sada rukovodio upravnik bolnice. Bolnica je od 1885. godine imala dve glavne ambulante, za internu medicinu i hirurgiju. Mnogi ugledni lekari su bili zaposleni u ovoj bolnici: Rihtarić, Mrazović, Šepić, Kosirnik i Vickerhauser. Do 1890. bolnica je imala 300 kreveta, što je zadovoljavalo potrebe pacijenata, ali su bolničke zgrade koristili i Državno porodilište, škola za babice i Institut za gluve. Pošto su potrebe postajale sve veće, red je prodao zgradu u ulici Ilica 83-85, a za uzvrat dobio imanje Vile „Socias“ i susedno groblje za siromašne, na lokaciji između ulica Vinogradska i Vrtlarska. Projekat za novi, veliki bolnički kompleks uradili su nemačke arhitekte Kuno i Vajdman. Zgrada je građena od 1893. do 1894. godine, kada je 15. jula nova, moderno opremljena bolnica počela rad. ${ }^{3}$

Za direktora bolnice je po useljenju u novu zgradu imenovan lekar. Promenom zdravstvenog zakona 1906. godine ponovo je bolnicom upravljao sveštenik koga su imenovale crkvene vlasti, dok je upravnik bio zadužen za disciplinu sestara. Doktor Ljudevit Jurak osnovao je 1913. godine Odeljenje za patologiju, koje danas nosi njegovo ime. Pre Prvog svetskog rata bolnica je postala jedan od najboljih medicinskih centara ne samo u Hrvatskoj, nego i u jugoistočnom delu Evrope. ${ }^{4}$

Tokom Prvog svetskog rata u bolnici je smešten veliki broj ranjenika, a mnogi lekari su bili mobilisani. Posle završetka rata bolnica je nastavila rad u novoj državi, Kraljevini SHS, potom Kraljevini Jugoslaviji. Ministarstvo narodnog zdravlja je 1924. godine sve bolnice razvrstalo u tri kategorije. U prvoj kategoriji bile su Opšta državna bolnica u Beogradu, Zakladna bolnica i Bolnica milosrdnih sestara u Zagrebu, Splosna bolnica u Ljubljani i još neke. Krajem februara objavljen je novi Zakon o zdravstvu, pa je u skladu sa novim propisima bolnica dobila zvaničan naziv „Opšta bolnica milosrdnih sestara za javnu upo-

\footnotetext{
${ }^{3}$ Klinička bolnica ,Dr. Mladen Stojanović“ Zagreb 1845-1985, priredio Vladimir Hudolin (Zagreb: Klinička bolnica „Dr. Mladen Stojanović“, 1985); Berislava Vračić i Alfonza Kovačić, Sestre milosrdnice Sv. Vinka Paulskog (Zagreb: Družba sestara milosrdnica Sv. Vinka Paulskog, 1996); Redovničke ustanove Sarajevo: Konferencija viših redovničkih poglavara i poglavarica Bosne i Hercegovine, http://www.redovnistvo.ba/hr/page.php?id=132 (pristupljeno 1. novembra 2018).

${ }^{4}$ Bolnica milosrdnih sestara u Zagrebu: Vodič kroz fondove i zbirke Državnog arhiva u Zagrebu, http://www.daz.hr/vodic/f-zdravstvo-i-socijalne-ustanove/f1-zdravstvene-ustanove-i-sluzbe/351hr-dazg-240-bolnica-milosrdnih-sestara-u-Zagrebu (pristupljeno 15. oktobra 2018).
} 
trebu“, jer je to bila privatna ustanova koju je mogla da koristi i javnost. U to vreme bolnica je raspolagala sa 939 postelja, imala je odeljenje za unutrašnja i nervna oboljenja, ginekološko, urološko, oftalmološko, dermatovenerološko, ORL i pedijatriju. U bolnici je radio i Institut za radiologiju, patologija i apoteka. Dve sobe su bile namenjene za posmatranje mentalno obolelih, a u besplatnoj ambulanti je pružana pomoć siromašnima. Između 1938. i 1941. godine osnovana su odeljenja za fizikalnu medicinu, neuropsihijatriju i ginekologiju. Od 1934. godine pa sve do 1946. red je opet preuzeo upravljanje bolnicom, a direktor je imenovan od strane vrhovne vlasti Reda.

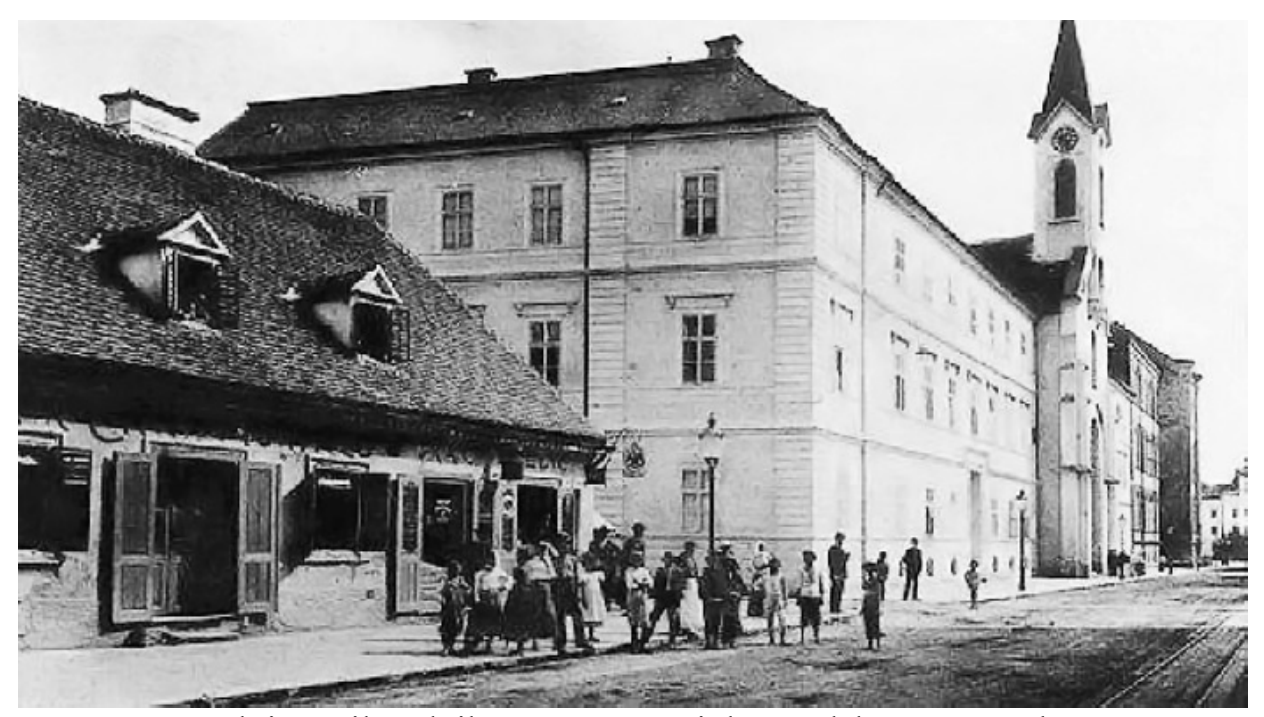

Bolnica milosrdnih sestara Sv. Vinka Paulskog u Zagrebu

Drugi svetski rat je prekinuo prosperitet bolnice. Pored civila u bolnicu su primani i mnogi ranjenici. Kraj rata je zatekao bolnicu u vrlom lošem stanju. Nakon formiranja socijalističke Jugoslavije, škole i bolnice svih redova katoličke crkve, kao i druga privatna imovina nacionalizovane su i od 1948. godine postale su vlasništvo države. Sestre su proterane iz svojih škola i bolnica i bile su primorane da rade u kancelarijama u građanskoj odeći, jer im je bilo zabranjeno da nose redovničku odeću, a sam opstanak reda je bio ugrožen. One su prihvatile ovu uredbu, ali su ipak nastavile da pomažu svima kojima je pomoć bila potrebna. Aktivnosti Reda u stvari nikada nisu prestale, sestre su nastavile sa dobrotvornim radom, ali u izolaciji o kojoj svedoči i visoki zid koji je tada podignut oko samostana.

U vreme socijalističke Jugoslavije bolnici je promenjeno ime u „Opšta bolnica dr Mladen Stojanović“", po lekaru iz Prijedora koji je ubijen 1942, a kasnije proglašen za narodnog heroja. Ova bolnica je od 1971. godine postala univerzitetska, pa se u njoj izvode nastava i praksa za osnovne i postdiplomske studije Medicinskog, Stomatološkog i Farmaceutskog fakulteta Sveučilišta u Zagrebu, kao i praksa za srednju školu za medicinske sestre i babice. Bolnici je 
naziv „Sestre milosrdnice“ vraćen 1992. godine, ali je ona i dalje ostala državno vlasništvo i danas radi pod nadzorom Ministarstva zdravlja Republike Hrvatske. Danas je Kliničko-bolnički centar „Sestre milosrdnice“, poznat i kao Vinogradska bolnica, moderan klinički centar sa 863 postelje, u kome je zaposleno 2.478 ljudi. Od 2010. godine u sastavu Kliničko-bolničkog centra nalaze se Klinika za tumore, u ulici Ilica, i Klinika za traumatologiju u Draškovićevoj ulici. Kliničko-bolnički centar „Sestre milosrdnice“ izdaje više časopisa, među kojima je najznačajniji Acta Clinica Croatica, međunarodni medicinski časopis za lekare i naučnike iz oblasti biomedicine. Časopis izlazi u kontinuitetu od 1962. godine i danas se nalazi u Science Citation Index Expanded. ${ }^{5}$

\section{Milosrdne sestre u Gradskoj bolnici u Zemunu}

Zemun je od 1739. postao pogranični grad Habzburške monarhije i to je ostao do 1918. godine. Od 1746. bio je u sastavu Vojne granice, a zbog pograničnog položaja postao je i sanitarna brana za epidemije zaraznih bolesti koje su se širile na teritoriji Osmanskog carstva. U Zemunu je otvoren i prvi kontumac (karantin) 1730. godine. ${ }^{6}$ Stanovništvo su, pored Srba koji su bili u većini, činili Nemci, Mađari i pripadnici drugih naroda. Kako je katoličkog stanovništva bilo dosta, podizane su i crkve, ali i druge institucije. Neke od njih su bile namenjene lečenju i smeštaju najsiromašnijeg sloja gradskog stanovništva. Iz ovakve jedne ubožnice razvila se katolička bolnica, osnovana 1758. godine, koja se kao i srpska bolnica u Zemunu izdržavala od privatnih priloga i novca koje bi crkva prikupila. Spajanje ove dve bolnice je izvršeno naredbom Generalne komande 15. februara 1784. kako bi se smanjili troškovi, čime je stvorena Gradska bolnica u Zemunu. ${ }^{7}$ Iako su još neko vreme radile u zasebnim objektima, uskoro se pristupilo izradi planova za gradnju nove zgrade bolnice. Generalna komanda je 1811. godine izdala Magistratu Zemuna Uputstvo o upravljanju bolnicom, po kome je izvršeno njeno uređenje. Zbog loših uslova u bolnici su se i dalje lečili uglavnom siromašniji slojevi, zanatlije, sluge, prosjaci. $^{8}$

Nova faza u razvoju Gradske bolnice započela je 1883. godine imenovanjem doktora Vojislava Subbotića za gradskog fizika. On je unapredio rad bolnice, pa je od bolničke kuhinje napravio operacionu sobu u kojoj je izvršio i prve hirurške zahvate. Uskoro je Gradsko zastupstvo donelo nekoliko odluka koje su bile bitne za dalji rad bolnice. Prvo je rešeno da se bolnici postavi ugovoreni staratelj, a zatim je usvojen novi Bolnički red (Diatenordnung). Posle pregovora, predstavnici

\footnotetext{
${ }^{5}$ Kliničko bolnički centar Sestre milosrdnice Zagreb, http://www.kbcsm.hr/\#/Home (pristupljeno 21. oktobra 2018); Acta clinica Croatica Zagreb: Sestre Milosrdnice University hospital and Institute of Clinical Medical Research, http://www.acta-clinica.kbcsm.hr (pristupljeno 21. oktobra 2014).

${ }^{6}$ Više o osnivanju Zemunske bolnice: Jasmina Milanović, Sanja Milenković, Momčilo Pavlović, Dragoš Stojanović, „Osnivanje Zemunske bolnice“, Srpski arhiv za celokupno lekarstvo, vol. 142, 7/8, (2014), 505-510.

7 Vladimir Bazala, „Dokumenti o zdravstvu u Vojnoj krajini, naročito o takozvanom kužnom kordonu“, Acta Historica medicinae pharmaciae, veterinae, 1-2, (1961), 64-82.

${ }^{8}$ Miodrag Dabižić, Zavičajni muzej - pregled prošlosti Zemuna (Beograd: Muzej grada Beograda, 1973), 21-25; Petar Marković, Zemun od najstarijih vremena pa do danas (Zemun: 1896), 109-122.
} 
grada su 2. avgusta 1887. sklopili ugovor sa milosrdnim sestrama Sv. Vinka Paulskog „radi primanja ovogradske bolnice u upravu na 10 godina“. Ugovor je potvrdilo Gradsko zastupstvo koje je rešilo da se u bolnici preduzmu veći adaptacioni radovi u iznosu od 2.500 forinti, a za nabavku nameštaja je dato još 500 forinti. Kada su radovi završeni, milosrdne sestre su 1. novembra primile upravu bolnice. Bolji uslovi u bolnici, red koji su uvele milosrdne sestre, njihovo znanje i zalaganje, uticali su na to da broj pacijenata koji je 1884. iznosio preko četiri stotine, 1888. godine postane dvostruko veći. Uz to se povećao i broj ambulantno lečenih pacijenata. U izveštaju Gradskog poglavarstva za upravnu 1888. godinu piše: „Primjetiti je da su milosrdnice u svakom pogledu, kako obzirom na njegu tako i na hranu, kao i inače na urednost i čistoću sve moguće učinile, da su neobičnim požrtvovanjem brižljivošću i odanjem i danju i noću nad bolesnicima lebdile, a ljekarima su bile pri ruci i od velike pomoći i pri operacijama kao pri svagdanjoj ordinaciji ambulantima, te su i s njihove strane mlogo doprinijele napretku i lijepom glasu ovogradske bolnice kako u samom gradu tako i u svoj okolici“" 9

Kako je broj stanovnika Zemuna bio u stalnom porastu, a broj pacijenata Gradske bolnice prevazilazio njene kapacitete, Gradska opština je započela pregovore sa Redom sestara milosrdnica o izgradnji nove bolničke zgrade, jer sama nije imala potrebna sredstva. Nakon uspešno završenih pregovora potpisan je ugovor.

\section{Ugovor Gradske opštine i Reda sestara milosrdnica o izgradnji nove bolničke zgrade ${ }^{10}$}

\begin{tabular}{|l|l|}
\hline I & $\begin{array}{l}\text { Red sestara se obavezao da će o svom trošku podići ,Opštu javnu bolni- } \\
\text { cu“ na zemljištu nekadašnje vojničke jahaonice i tadašnje bašte koju su } \\
\text { koristile milosrdnice, s tim da bolnica bude vlasništvo istog reda. }\end{array}$ \\
\hline II & $\begin{array}{l}\text { Bolnička zgrada i sve prostorije u njoj moraju u svemu odgovarati posto- } \\
\text { jećim propisima i u njoj mora biti najmanje } 100 \text { bolničkih kreveta, a osim } \\
\text { ostalih potrebnih prostorija, mora biti dovoljan broj separatnih soba za } \\
\text { bolesnike boljeg staleža, te i dovoljan broj soba za motrenje umobolnih. } \\
\text { U slučaju povećanja broja bolesnika koji traže bolničko lečenje, Red se } \\
\text { obavezao da će zgradu proširiti. }\end{array}$ \\
\hline III & $\begin{array}{l}\text { U vlasništvu Reda su dve pomenute zemljišne parcele, svi medicinski } \\
\text { instrumenti i celokupni bolnički nameštaj, pribor i rublje. }\end{array}$ \\
\hline IV & $\begin{array}{l}\text { Red se obavezao da će preuzeti i druge dužnosti koje su navedene u po- } \\
\text { sebnim tačkama. }\end{array}$ \\
\hline V & $\begin{array}{l}\text { Red će preuzeti pristojno izdržavanje i negu ubogih o nemoćnih građana, } \\
\text { koji će ostati u prostorijama stare bolničke kuće u Bežanijskoj ulici, a } \\
\text { koja će ostati u vlasništvu opštine. U pogledu ove ustanove (ubožnice) } \\
\text { sklopiće se posebni ugovor u kojem će se ustanoviti i cena izdržavanja. }\end{array}$ \\
\hline VI & $\begin{array}{l}\text { Opština grada je zadržala pravo na dve besplatne postelje III razreda u } \\
\text { ime naknade za poklon koji je naveden u tački III. Osim toga opština je }\end{array}$ \\
\hline
\end{tabular}

\footnotetext{
${ }^{9}$ Izveštaj Poglavarstva grada Zemuna za upravnu 1888. godinu (Zemun, 1890).

${ }^{10}$ Tekst ugovora je preuzet iz: Miodrag Dabižić, „Prvi hospitali i bolnički fond“, u: Dvesta godina Zemunske bolnice 1748-1984 (Beograd: Kliničko bolnički centar Zemun, 1985), 10-16.
} 


\begin{tabular}{|c|c|}
\hline & $\begin{array}{l}\text { zadržala pravo da građani Zemuna za lečenje u sobi III razreda plaćaju } \\
40 \mathrm{n} \text {. ( } 80 \text { pa } 90 \text { filira) dnevno. Ako njihov broj bude veći od 12, onda će } \\
\text { bolnički dan biti } 50 \mathrm{n} \text {. ( } 1 \text { kruna). Utvrđeno je, takođe, da se Red podvr- } \\
\text { gava opštem cenovniku za javne bolnice, koji propisuje Zemaljska vlada. } \\
\text { Ovo ograničavanje nije se odnosilo na separatne sobe koje su korisnici } \\
\text { plaćali prema propisima Reda. }\end{array}$ \\
\hline VII & $\begin{array}{l}\text { Ovim Ugovorom prestala je da važi obaveza grada u pogledu obezbeđi- } \\
\text { vanja lekara. Ona je prešla u nadležnost Reda koji je birao osoblje i s } \\
\text { njim ugovarao nagradu. }\end{array}$ \\
\hline VIII & $\begin{array}{l}\text { Dosadašnji ugovor koji je između grada i Reda sklopljen } 2 \text {. avgusta } \\
\text { 1887, prestaje da važi u onom času kad se sagradi, uredi i komisijski } \\
\text { primi nova bolnička zgrada. Tada će na snagu stupiti novi, odnosno ovaj } \\
\text { ugovor koji će biti potvrđen od viših organa. }\end{array}$ \\
\hline IX & $\begin{array}{l}\text { Pošto prema propisima Gradsko poglavarstvo mora vršiti nadzor nad } \\
\text { upravom javnih bolnica, one će u tom cilju iz svoje sredine birati posebni } \\
\text { odbor - Zdravstveni odbor. }\end{array}$ \\
\hline$X$ & $\begin{array}{l}\text { (U ovoj tački navedeni su brojevi katastarskih čestica i površine parcela } \\
\text { koje su predate Redu) Kužno groblje, koje će Red koristiti za bašte, u } \\
\text { slučaju pojave epidemije dužno je da koristi za smeštaj drvenih baraka za } \\
\text { obolele od infektivnih bolesti. Gradska opština će u pripravnosti držati } \\
\text { odgovarajuću montažnu baraku koja treba da primi najmanje } 30 \text { bolesni- } \\
\text { ka. Redu se nalaže da vodi upravu i da brine za sve propisane potrebe } \\
\text { bolnice i bolesnika, uz naknadu koju će plaćati interesenti i grad. }\end{array}$ \\
\hline XI & $\begin{array}{l}\text { Red se obavezao da će tokom vremena, ako nastupe javni obziri i osobite } \\
\text { okolnosti budu iziskivale, Bolnicu ustupiti gradu ili Zemaljskoj vladi, uz } \\
\text { cenu, koja će se nagodbom, a eventualno sudbenom procjenom ustanoviti. } \\
\text { (Ova tačka nije mnogo odgovarala Redu i prilikom kasnijih pregovora } \\
\text { uvek su nastojale da se ova obaveza izbaci, jer su je smatrale za „smrtnu } \\
\text { osudu koja je priječila sva daljnja razvijanja Bolnice“). }\end{array}$ \\
\hline XII & $\begin{array}{l}\text { Sva zaveštanja, zapisi i darovanja namenjena Gradskoj bolnici pripadaju } \\
\text { gradskoj Bolničkoj zakladi za negu bolesnika grada Zemuna. }\end{array}$ \\
\hline XIII & $\begin{array}{l}\text { Ugovor stupa na snagu onog dana kad ga prihvati Gradsko zastupstvo } \\
\text { Zemuna i odobri Zemaljska vlada u Zagrebu. S izvesnim ispravkama } \\
\text { najviši organ ga je odobrio 31. marta } 1892 \text {, odnosno } 6 \text {. jula } 1893 \text {. }\end{array}$ \\
\hline
\end{tabular}

Odmah po okončanim pregovorima i potpisivanju ugovora počela je gradnja nove troetažne zgrade s čeonim delom prema Vrtlarskoj ulici i dva dvorišna krila prema planovima koje je 1890. godine potpisao Johan Nepomuk Hole iz Slavonske Požege, koji je uradio i nadzirao gradnju i drugih bolnica milosrdnih sestara. Do jeseni 1891. radovi su završeni i 4. oktobra zdanje je osvećeno i otvoreno uz prisustvo superiora reda Fidelisa Hepergera iz Zagreba. U skladu sa ugovorom Gradsko poglavarstvo je 1892. godine izabralo Odbor za nadzor nad Gradskom bolnicom, a posle donošenja Zakona o zdravstvu 1894. 
godine, biran je Zdravstveni odbor Gradskog zastupstva, koji je imao više članova na čelu sa načelnikom grada.

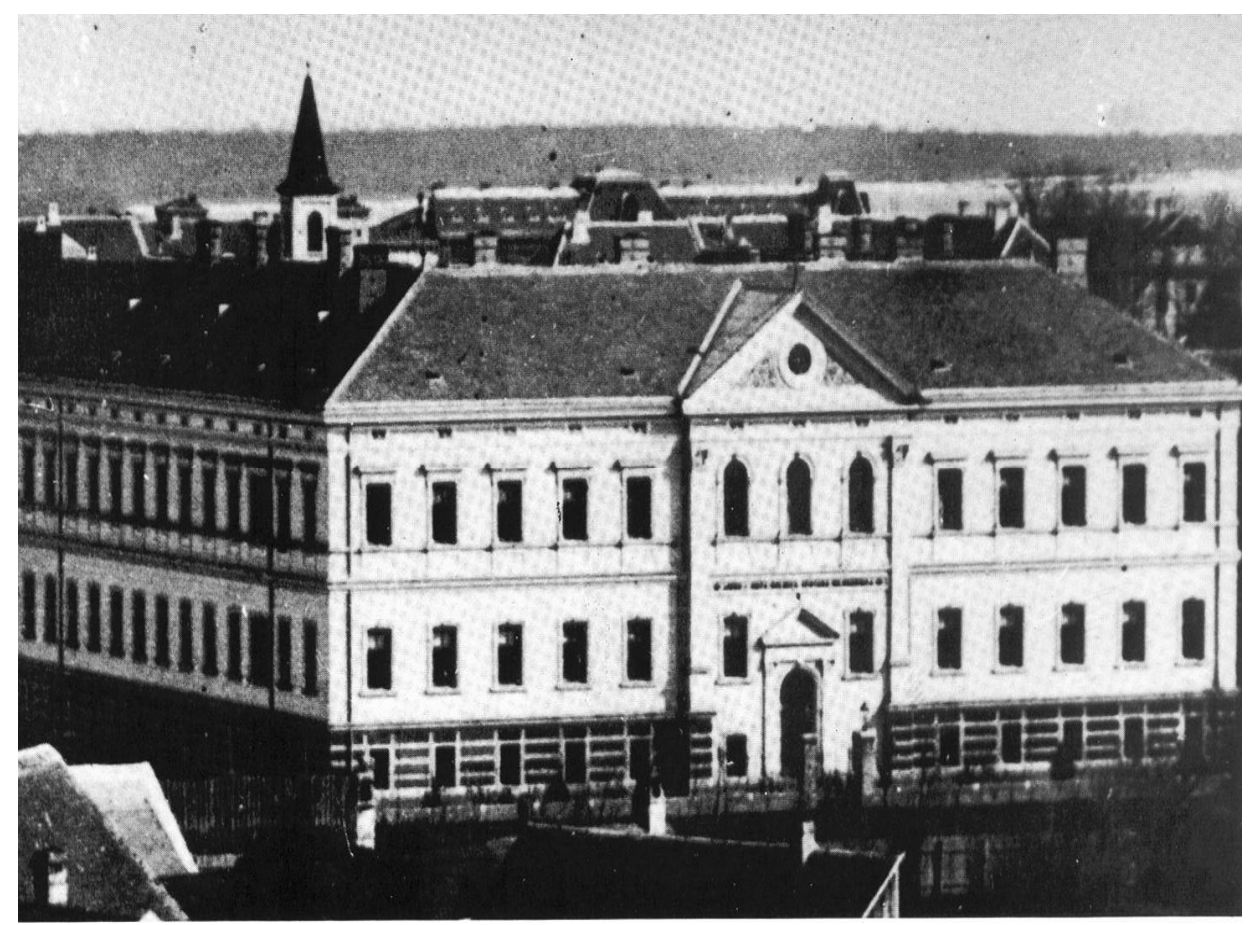

Prvobitna zgrada Opšte i javne bolnice milosrdnih sestara u Zemunu

Sestre milosrdnice su dobro brinule o pacijentima i čistoći bolnice, što se vidi i iz izveštaja Odbora čiji su članovi često obilazili bolnicu i to bez najave. Uskoro je u dvorištu bolnice iskopan novi bunar kako bi se poboljšalo snabdevanje vodom. Uprava bolnice je 1899. godine na bolničkom zemljištu u Vrtlarskoj ulici sagradila prizemnu zgradu za infektivne bolesnike, koji su se do tada nalazili u objektu na Bežanijskoj kosi. Osim ovih radova, posebna pažnja je posvećena opremanju bolnice, pa je 1901. godine nabavljen Rendgenov aparat, a kasnije i sterilizator. Bolnica je, zbog povećanog broja pacijenata, opet proširena 1905. godine nadogradnjom treće etaže na čeonom delu zgrade. U bolnici su sestre milosrdnice i stanovale, a imale su lepo uređenu kapelu i druge prostorije koje su im bile potrebne. Posle dogradnje sprata došlo je do izmena u organizaciji i rasporedu prostorija i opreme. Bolnica je do tada imala samo Opšte odeljenje, a sada je dobila tri odeljenja - hirurško, interno i venerično. U jesen 1913. Red je od udovice doktora Alberta Talera kupio kuću izgrađenu 1890. godine, koja je uređena za stanovanje bolničkog lekara i duhovnika. ${ }^{11}$

\footnotetext{
${ }^{11}$ Videti: M. Dabižić, D. Ostojić, U. Hadžagić, D. Gril, T. Janjatović, R. Ninković, Z. Jocić, Dvesta godina Zemunske bolnice 1748-1984 (Beograd: KBC „Zemun“, 1985); Risto Jeremić, Medicinske prilike и Zeтипи 1750-1900 (Beograd: Biblioteka Centralnog higijenskog zavoda, 1937).
} 


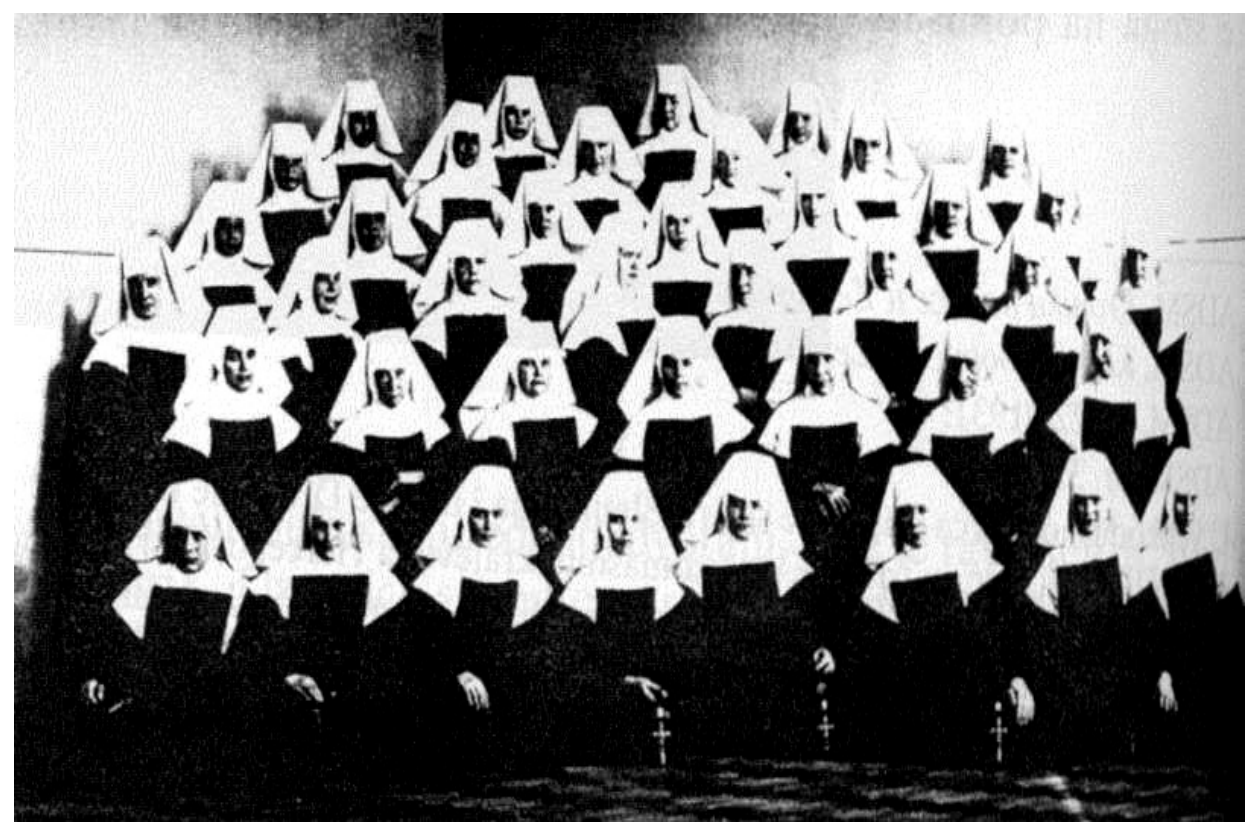

Družba sestara milosrdnica Sv. Vinka Paulskog

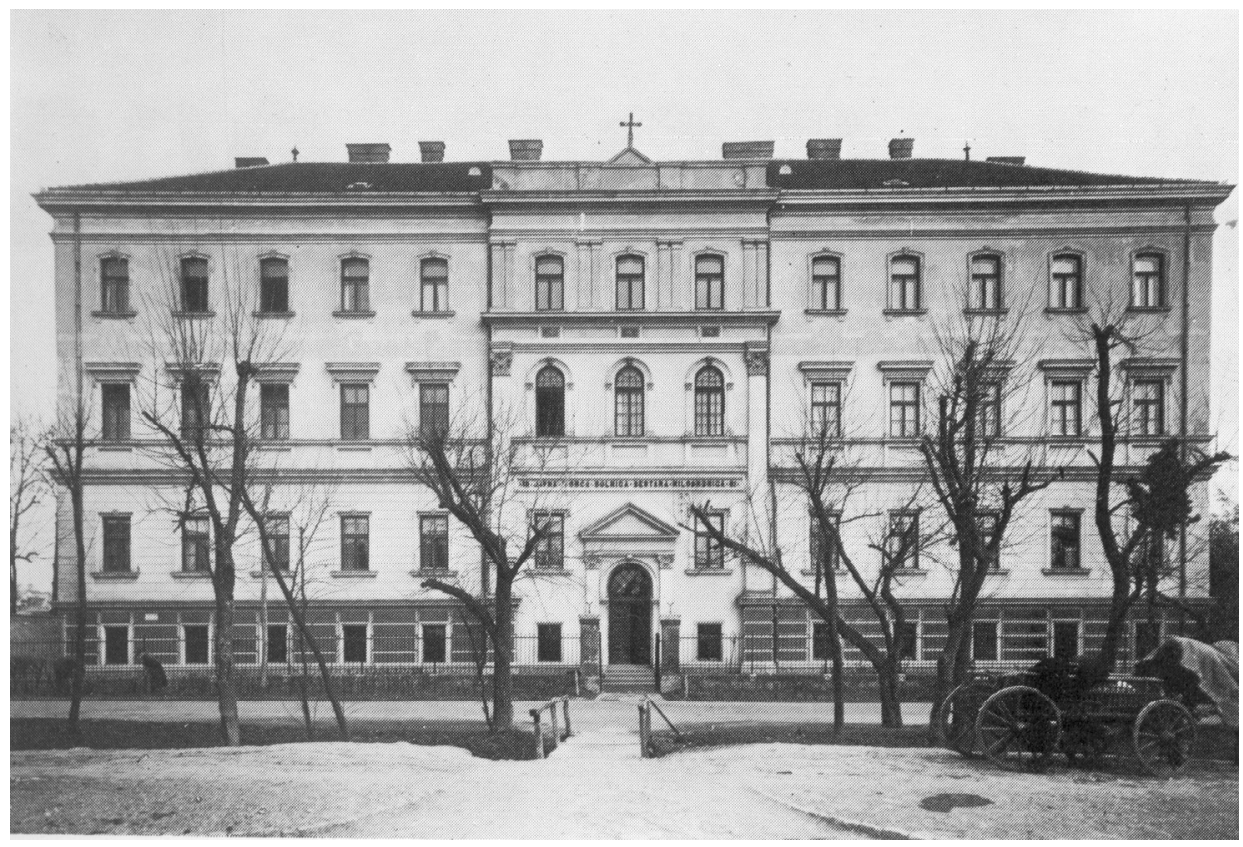

Prema planovima Franje Jenča 1905. godine dograđen je još jedan sprat na čeonom delu zgrade 
Tokom Prvog svetskog rata Zemun je opet bio na prvoj liniji ratnih sukoba. U bolnici su lečeni brojni ranjenici, a ordinirali su i vojni lekari, pored postojećeg osoblja.

\section{Opšta bolnica u Zemunu 1918-1948.}

Kada je 5. novembra srpska vojska oslobodila Zemun, ovaj grad se našao u novoj državi Kraljevini SHS. Bolnica je nastavila rad pod upravom Reda milosrdnih sestara i pod istim nazivom. Jedino je 18. decembra 1918. nastojništvo Reda premestilo predstojnicu i upraviteljicu sestru Raspor, posle 31 godine predanog rada u Gradskoj bolnici u Zemunu, na istu dužnost u bolnicu u Zagrebu. Za predstojnicu Zemunske bolnice postavljena je sestra Frederika, koja je do tada upravljala zagrebačkom bolnicom. Po novoj kategorizaciji iz 1924. godine bolnica u Zemunu se našla u drugoj kategoriji. Za novu predstojnicu bolnice je početkom februara 1924. postavljena sestra Eleuhadija koja je ubrzo započela sa uređivanjem bolničke zgrade. Adaptirana je kuhinja, uvedena kanalizacija, uređena perionica, kasnije opremljena mašinama za pranje, sušenje i peglanje rublja, a izvedeni su i vodoinstalaterski radovi i postavljene nove keramičke šolje. Osim toga, izvedeni su veliki radovi u dvorištu, postavljena je ograda, zasvođen kanal, izgrađene staze.

Uredbom o podeli Kraljevine SHS na oblasti, Zemun je bio uvršten u Sremsku oblast sa sedištem u Vukovaru, sve do 1929. godine. Skupština Sremske oblasti je bila nadležna, između ostalog, i za oblast zdravstva, pa je i rad bolnice u Zemunu bio u njenom domenu. Oblasni organi su pratili rad, pregledali račune, kontrolisali red i čistoću. Na kraju je utvrđeno da državni organi duguju bolnici znatnu sumu novca, preko 300.000 dinara, što je uplaćeno bolničkoj blagajni 1929. godine. Taj novac je kasnije iskorišćen za nova proširenja bolničke zgrade. $^{12}$

U ovom periodu bolnica je imala četiri odeljenja - interno, hirurško sa rodilištem, venerično i odeljenje za zarazne bolesti. U bolnici je radilo 6 lekara, 40 milosrdnih sestara i pomoćno osoblje, imala je 268 postelja, a godišnje je lečeno preko 3.000 pacijenata. Kada je 1930. godine isteklo šest godina (dva mandatna perioda) starešinstva predstojnice sestre Eleuhadije, Red se obratio nadležnom organu u Rimu i Sveta Stolica je odobrila da ona ostane za „treće trogodište“.

Upravnik bolnice je od 1921. bio dr Ivan Baboselac (1885-1949), hirurg. On je uporno tražio da se poveća bolnički kapacitet, što je 1930. najzad odobreno s tim da se dogradi drugi sprat na bočnim krilima bolničke zgrade. Tokom ovih radova završeno je uvođenje centralnog grejanja. Bolnica je posle ove dogradnje imala 400 postelja, podeljenih u pet odeljenja: hirurško, interno, dermatološko, infektivno i očno, a obnovljena je i bolnička apoteka.

\footnotetext{
12 Sremski glasnik, 24. 3. 1929, VI, 12, 2; Sremski glasnik, 19. 3. 1929, VI, 20, 2.
} 


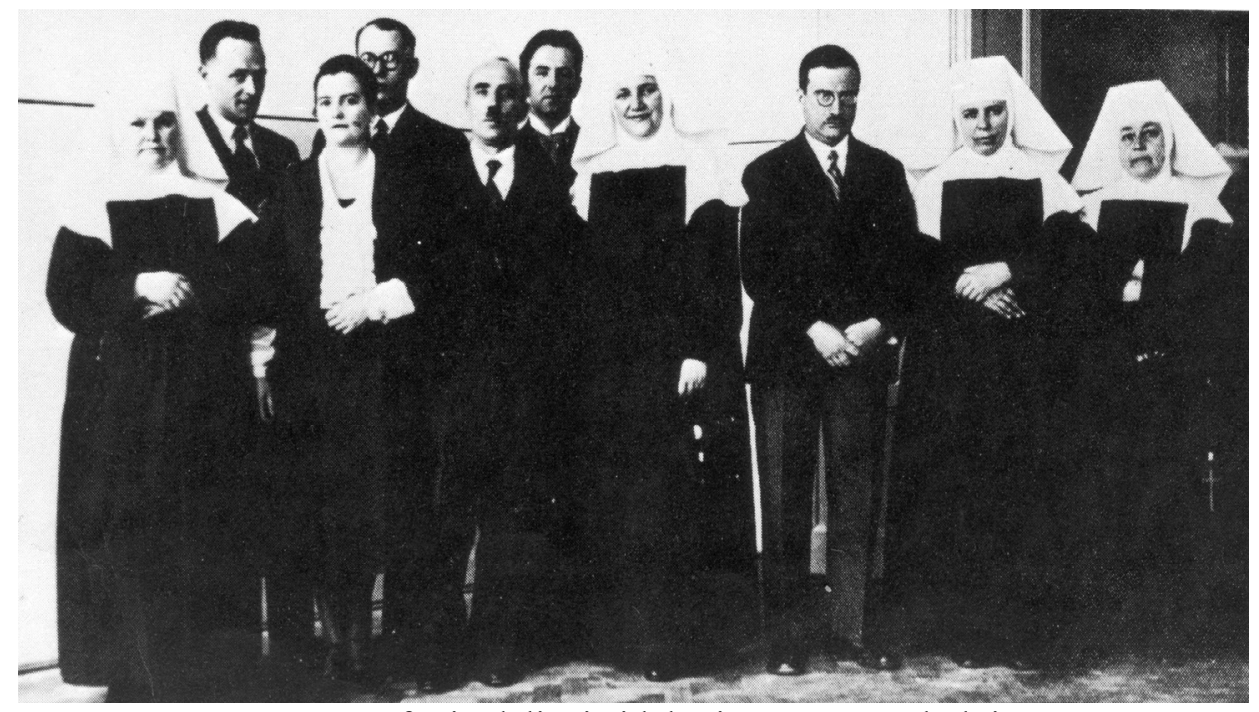

Uprava, šefovi odeljenja i lekari Javne opšte bolnice

prilikom proslave 40 godina rada u novoj zgradi bolnice, 1931. godine.

Treći sleva u prvom redu: dr Ivan Baboselac

Milosrdne sestre su imale svoju ekonomiju u neposrednoj blizini grada na kojoj su organizovale proizvodnju nekih ratarskih i povrtarskih kultura, ali su gajile i stoku. Svoje imanje su proširivale i kupovinom zemljišta, poput majura koji su kupile od porodice Smederevac. Starale su se da sa ekonomije ostvare i prihode, jer su zbog radova na bolnici nekada morale da se zadužuju, pa su deo dugova otplaćivale i tako zarađenim novcem. U Vrtlarskoj ulici su 1936. godine kupili kuću, koju su uredile za stanovanje, sa baštom. Na mestu na kome se nalazila Telerova vila, do 1939. godine izgrađena je dvospratna zgrada sa ulazom prema parku. Ovaj Dom sestara milosrdnica, koji je bio zapravo njihov samostan, imao je prostrane sobe sa svim propratnim prostorijama. Kapela, arhiva, trpezarija, kuhinja i magacini su ostali u bolničkoj zgradi. Preseljenjem sestara kapacitet bolnice je uvećan za još 100 postelja. ${ }^{13}$

Drugi svetski rat je ponovo doneo promene i u gradu Zemunu, koji će postati opet pogranični grad u sastavu Nezavisne Države Hrvatske. Bolnica je ostala pod upravom milosrdnih sestara i nastavila je rad s malom izmenom u nazivu, sada se zvala „Opća bolnica sestara milosrdnica s pravom javnosti u Zemunu“. Posebno teški uslovi su se ticali snabdevanja hranom i lekovima, pa je sestrama bilo teško da održavaju red kakav je ranije vladao. Posle oslobođenja Zemuna 22. oktobra 1944. bolnica je nastavila da radi kao vojna ustanova do oktobra 1945. godine, kada postaje civilna bolnica pod imenom „Javna opšta bolnica - Zemun“. Sestrama je bilo dozvoljeno da nastave da žive u svom

\footnotetext{
${ }^{13}$ Više o radu bolnice u ovom periodu: Sanja Milenković, Jasmina Milanović, „Kliničko bolnički centar Zemun kroz vekove - 20. vek“, Materia medica, god. 30, br. 1, (2014), 1004-1017.
} 
objektu i rade u bolnici. Tokom 1945. godine u bolnici je radilo 29 lekara, a imala je odeljenja interne medicine, pedijatrije, dermato-venerologije, hirurgije, ginekologije i akušerstva, rendgen kabinet, laboratorije i apoteku. U narednom periodu više puta je menjano ime bolnice pa je tako 1954. registrovana pod imenom Gradska bolnica, 1965. kao Opšta bolnica u Zemunu, od 1973. nosila je naziv Klinička bolnica u Zemunu, da bi 1983. godine dobila ime koje nosi i danas - Kliničko-bolnički centar Zemun. 


\section{REFERENCE}

- Bazala, Vladimir. „Dokumenti o zdravstvu u Vojnoj krajini, naročito o takozvanom kužnom kordonu“. Acta Historica medicinae pharmaciae, veterinae, 1-2, (1961), 64-82.

- Dabižić, Miodrag. Zavičajni muzej - pregled prošlosti Zemuna. Beograd: Muzej grada Beograda, 1973.

- Dabižić M., D. Ostojić, U. Hadžagić, D. Gril, T. Janjatović, R. Ninković, Z. Jocić. Dvesta godina Zemunske bolnice 1748-1984. Beograd: KBC „Zemun“, 1985.

- Izveśtaj Poglavarstva grada Zemuna za upravnu 1888. godinu. Zemun, 1890.

- Jeremić, Risto. Medicinske prilike u Zemunu 1750-1900. Beograd: Biblioteka Centralnog higijenskog zavoda, 1937.

- Klinička bolnica „Dr. Mladen Stojanović“ Zagreb 1845-1985. Priredio Vladimir Hudolin. Zagreb: Klinička bolnica „Dr. Mladen Stojanović“, 1985.

- Marković, Petar. Zemun od najstarijih vremena pa do danas. Zemun, 1896.

- Milanović, Jasmina, Sanja Milenković, Momčilo Pavlović i Dragoš Stojanović. „Osnivanje Zemunske bolnice“. Srpski arhiv za celokupno lekarstvo, vol. 142, 7/8, Beograd, (2014), 505-510.

- Milenković Sanja, i Jasmina Milanović. „Kliničko bolnički centar Zemun kroz vekove - 20. vek“. Materia medice, vol. 30, br. 1, (2014), 1004-1017.

- Vračić Berislava, i Alfonza Kovačić. Sestre milosrdnice Sv. Vinka Paulskog. Zagreb: Družba sestara milosrdnica Sv. Vinka Paulskog, 1996. 
JASMINA MILANOVIĆ, PhD, Senior Research Associate

Institute for Contemporary History

Belgrade, Republic of Serbia

jasmina.mil17@gmail.com

SANJA MILENKOVIĆ, PhD, Full Professor

Clinical Department of Pathology CHC Zemun

Belgrade, Republic of Serbia

sanjamilenkovic3@gmail.com

MARINA KOS, PhD, Full Professor

Faculty of Medicine, University of Zagreb

Zagreb, Republic of Croatia

marina.kos@kbcsm.hr

THE ACTIVITY OF THE ORDER OF THE SISTERS OF CHARITY OF ST. VINCENT DE PAUL IN HOSPITALS IN ZEMUN AND ZAGREB

\section{Summary}

The work of the oldest medical facility on Serbian territory - the Zemun hospital, is inextricably connected with the arrival of the Sisters of Mercy of the Order of St. Vincent de Paul. The Order started forming in 1617 when the French priest Vincent de Paul began to gather women who were willing to help the poor and the sick. The official founding date of the Order is the year 1633 . The first six sisters arrived in Zagreb in 1845, where they started taking care of patients within the monastery premises. This was the oldest hospital in Croatia. They arrived in Zemun in 1887 when they signed a contract with the city authorities and took over the management of the City Hospital. Thanks to their good administration and organization, the hospital got a new building and became a modern medical facility that provided professional help.

greb, Zemun

KEYWORDS: Hospital, Sisters of Charity, History of Medicine, Za- 